\title{
A Linguistic Analysis of Cultural Content in French-English Translation of a Yoghurt Commercial
}

\author{
Językoznawcza analiza treści kulturowych \\ w tłumaczeniu reklamy jogurtu z języka francuskiego na angielski
}

\author{
Arkadiusz JANCZYŁO ${ }^{1}$ \\ Ateneum-Szkoła Wyższa w Gdańsku
}

\begin{abstract}
Advertising translation is a multifaceted practice which poses specific challenges for translators that extend beyond sheer linguistic competence of the professionals involved in the process. Cross-cultural awareness and sensitivity are called for when dealing with translating commercial matter internationally and interculturally. This paper presents a comparative analysis of a TV commercial of natural yoghurt and its representation in two languages. The advert was originally created in French, subsequently translated and dubbed in English by a French-accent English speaker. The English version deviates slightly linguistically and culturally from its French counterpart. The notions of explicitation, equivalence, adaptation and localisation applied in this paper provide grounds for analysis of a range of translation decisions and strategies which allow to achieve similar advertising pragmatic effects as well as add extra dimensions that are absent in the source text.
\end{abstract}

Keywords: adaptation, advertising, equivalence, explicitation, localisation, multidimensionality, translation

\section{Streszczenie}

Tłumaczenia reklamowe to przykład wielowarstwowego przekładu, który przed tłumaczem stawia konkretne wyzwania wykraczające poza zwyczajowe kompetencje językowe osób

1 (D) https://orcid.org/0000-0002-2172-4791. 
zaangażowanych w ten proces. Świadomość oraz wrażliwość międzykulturowa są nieodzowne przy przekładzie materii komercyjnej w kontekście międzynarodowym jak i międzykulturowym. Niniejsza publikacja przedstawia analizę reklamy telewizyjnej jogurtu naturalnego. Reklama została stworzona oryginalnie $\mathrm{w}$ języku francuskim, a następnie przełożona na angielski $\mathrm{w}$ formacie dubbingu $\mathrm{w}$ wykonaniu przez osobą mówiącą $\mathrm{w}$ języku angielskim $\mathrm{z}$ silnym akcentem francuskim. Wersja angielska reklamy odchodzi nieznacznie językowo i kulturowo od wersji francuskiej. W analizie zastosowane będą koncepcje eksplicytacji, ekwiwalencji, adaptacji oraz lokalizacji, które to posłużą wyjaśnieniu i omówieniu decyzji i strategii przyjętych w przekładzie pozwalających uzyskać podobny efekt reklamowy oraz dodających wymiary nieobecne $\mathrm{w}$ wersji oryginalnej.

Słowa kluczowe: adaptacja, eksplicytacja, ekwiwalencja, lokalizacja, przekład, reklama, wielowymiarowość

\section{Introduction}

Advertising translation is usually associated with the interlingual transfer of advertisements which aims at internationalizing a product in different languages. According to Cristina Valdes (2013), advertising performs the following functions: 1) communicates an obvious intention while promoting or selling; 2 ) transmits the values of a product or a brand; 3 ) reflects or exports the values of a definite culture; 4) provides a product's essential specifications, etc (p. 303).

The aim of this paper is to investigate the notions of linguistic equivalence and localisation in relation to the French (source language) and English (target language) advertisements of Perle de Lait yoghurt as advertised on French and English television (dated 2010). The English dubbed translation of the advertisement shall be analysed against the source language with reference to two translation strategies. The first type strategy (linguistic equivalence) is understood as literal rendering of the source language (SL-hereafter) in the target language (TL-hereafter), whereas the second strategy constitutes adaptation. The study also addresses the aspect of how localization of the advertisement is achieved through said strategies. Eventually, the same translation and adaptation techniques will be discussed as to whether they would promote the same effect in the Polish cultural setting. Every attempt has been made to locate the product advertisement in Polish. Still, the Polish market does not yet benefit from this particular food product, thus that part of the discussion is purely theoretical in nature. 


\section{Theoretical framework}

The comparative analysis focuses on the linguistic and cultural aspects of the two advertisements promoted through a particular use of lexis and dialect as well as the effects these elements evoke in the English audience. The discussion shall be informed by the theory of explicitation (Blum-Kulka, 2004) and register analysis (Hatim and Mason, 1994) which, in turn, will serve as the basis for assessing the extent of linguistic equivalence and localisation between the French and English versions of the advertisement, alongside with evaluating their contribution to creating a desired perlocutionary effect.

Advertising is a multi-faceted marketing practice and different marketing techniques are applied to attract a potential customer's attention to a given product (Valdes, 2013). The marketing techniques that find application in the advertisements analysed in this study rely upon evoking certain cultural associations with culture-specific references. Visually, the English version of the advertisement is almost identical to the French one with the only exception of the yoghurt flavour selection available in both cultures; however, this aspect lies beyond the scope of this analysis. Interestingly, although the two advertisements are virtually the same visually, they both appeal to their audiences' senses through different means. For easier reference purposes, full French (SL) and English (TL) transcripts of the advertisement have been included in Appendix A, with the French version accompanied by backtranslation.

\section{Advertisements analysis}

The advertisement was originally created for the French audience and then the product was also made available to the British customer and thus an English advert was created. The commercial could be analysed on multiple plains, such as non-linguistic: the pitch of the actress's voice, her intonation, facial expressions, the number and sequence of particular images, the advertisement's length, and linguistic ones: the choice and use of lexis, emphatic language, etc. It is suggested that the ultimate effect of the advertisement is a sum of all its elements, of which only linguistic and cultural aspects shall be analysed below.

In terms of explicitation, the concept is applied in this paper in an extended way to what Vinay \& Darbelnet (1958) and Blum-Kulka (2004) offer. As a tool which addresses issues where a translator states information more explicitly in the target text than it is expressed in the source by adding and/or spelling out what is merely implied in the original, the concept also lends itself 
to a wider analysis in translation. It can be used to provide for differences in semiotic and cultural expression between source and target texts. It is postulated in this paper that the English advertisement is added a cultural layer, making it more explicit in terms of how Frenchness is received in the target culture in the context of food and cuisine. It shall also be put forward in this essay that the extent of explicitation in the advertisements prompts a debate, rather than proposes a definite answer, as to whether the English advertisement is a translation of the French one or rather an adaptation in line with Bastin (2001).

As a means to express culture, explicitation is here postulated to be a useful tool to address issues of how culture is present in the language, whether source or target, via discourse. This paper presents a view that the two advertisements are not equally culturally explicit in this regard. What is more, the explicitation relates to different cultural phenomena being emphasised in both language versions. One obvious instantiation is exemplified in the phonetic layer of the commercials. The element of a foreign accent employed in the English version is absent from the French advertisement. In the French cultural setting there are neither means nor necessity to refer to any foreign cuisine through an exotic-sounding dialect in order to advertise better a given food product. The French pride themselves on their tasty cuisine.

\subsection{Explicitation in the English commercial}

The study looks into three examples of explicitation in the English advertisement, and subsequently compares them with the French translated variants in terms of explicitation. The English version (Appendix A 3.1-3.5), for instance, applies Dryden's paraphrase (1926) in 3.2 'and you could see that I wasn't happy about it' which seems more explicit than French (Appendix A 1.1-1.5) 1.2 'C'était pas terrible.' [2.2 It wasn't bad.]. It is possible to claim that the two phrases 3.2 and 1.2, though functionally similar and relevant, promote two different mental images. Entry 3.2 presents evidently negative perception, whereas 1.2, though it may be understood as [it wasn't really good], still accounts for some positive appreciation, and its message is not purely negative.

The next example which seems significantly more explicit in English than in French is illustrated in 3.3 'Then one day I discovered the silky smoothness of Perle de Lait (...)'. It stands in for French 1.3 'Puis un jour, j'ai découvert la douceur de Perle de Lait (...)' [2.3 Then one day I discovered the softness of Perle de Lait (...)]. In the fragment the phrase 'silky smoothness' renders a pre-modified synonym to French 'douceur' [softness]. English 
'smoothness' appears more explicit through the use of a pre-modifying adjective 'silky' and attempts to generate association with something much 'softer' than in the French variant of advertisement.

The third example concerns the use of the word 'transformer' in French 1.3 - 'Puis un jour, j'ai découvert la douceur de Perle de Lait et mon visage s'est transformé.' [2.3 Then one day I discovered the softness of Perle de Lait, and my face transformed.] and the use of the phrasal verb 'lit up' in the English advert -3.3 'Then one day I discovered the silky smoothness of Perle de Lait, and my face lit up.' The TL commercial appears more explicit here through the fact that 'my face lit up' is a hyponym of the superordinate French structure 's'est transformé' [transformed]. A face can transform in many ways, and 'lighting up' is one of such ways. The French ad relies here on an elliptic use of the word 'transformer' in conjunction with the visual content to suggest a positive change, whereas the English ad utilises a hyponym to inform the viewer specifically how the face transformed through lighting up with pleasure.

\subsection{Explicitation in the French commercial}

Regarding the French advertisement three examples are identified for higher explicitation in French in comparison to the English version. The first example concerns how yoghurt in 1.1 rendered in terms of defining it. French 1.1 'Avant, je ne mangais que des yaourt nature ordinaire (...)' [2.1 Before, I only used to eat ordinary natural yoghurt (...)] becomes English 3.1 'I used to eat extremely sour yoghurt'. The French version specifically calls ordinary natural yoghurt sour, whereas the English version omits the reference in favour of 'yaourt nature ordinaire' [ordinary natural yoghurt] and uses an extreme premodifier to refer to 'extremely sour yoghurt' without.

The second example is part of the same sentence relates to the phrase 'extrement acide' in 1.1 'Avant, je ne mangais que des yaourt nature ordinaire, extrement acide.' [2.1 Before, I only used to eat ordinary natural yoghurt, extremely acidic.]. Through placing 'extrement acide' at the end of the sentence and reinforcing it with a high voice pitch and a facial expression indicating having eaten something sour, it creates a direct (Searle, 1979) perlocutionary effect (Austin, 1962) intending to evoke a strong emotional impression on the viewer. This emphatic distance between the sentence and the phrase is lost in the English ad, which paraphrased it into casual 'extremely sour yoghurt' 3.1 'I used to eat extremely sour yoghurt' - without any emotional colouring through the use of voice pitch whatsoever. 
The third instance refers to the use of French 'succombé au doux parfum' in 1.5 'Et maintenant succombez au doux parfum vanille de perle de lait saveur vanille.' [2.5 And now succumb to the delicate scent of vanilla of Perle de Lait Vanilla]. Unlike the English advertisement, which resorts to the terms 'temptation' and 'new pleasure' - 3.5 'Yield to the temptation of new pleasure.' - the French version attempts to persuade the viewer to 'succumb to the delicate scent of vanilla of Perle de Lait (...)' through referring to a more specific association. The SL spot resorts to a very concrete way of tempting, namely, through a pleasant scent, to consume the pleasure which Perle de Lait explicitly provides.

\subsection{The role of accent}

Geographical dialect (Hatim and Mason 1994, pp. 39-40) is another aspect employed in the English advert. In spoken discourse, in particular, it is claimed not only to facilitate the perception of a person, but also to contribute to the meaning and reception of the discourse. Thus dialects, through possessing certain qualities, evoke particular references and associations.

In the English advertisement a strong geographical dialect has been applied as another very distinctive and UK culture-specific localisation factor. The product is advertised by a woman speaking in English with a distinctive French accent. This technique, which may be called localising through foreignisation, due to the fact that it exoticises the product to a certain extent, facilitates evoking a specific association in the target audience. Namely, among the British there exists a general trend to regard French food as quality food. Thus, the French-sounding woman enjoying her yoghurt in a TV advertisement reinforces an association of the product with other tasty French food and adds more sophistication to the product, which in turn leads to the UK audience regarding it with greater respect.

\subsection{Polish cultural setting implications}

While analysing the role of geographical dialect in the English commercial and its effect on the viewer of the advertisement, another interesting point appeared. As suggested above, particularly in the context of advertising in the UK, the French accent may play a significant role in the positive perception of a product by the British audience. Thus, if the advert was to be translated and broadcast on TV in Poland, for instance, it is supposed that the use of the same dialect might bear a different significance for creating a particular product image. 
For instance, in Poland it is much less common to associate French food with exclusive taste and exceptional quality. What is more, familiarity with French cuisine is much more limited than in the UK. In general, Polish food is regarded as tasty and so there is no particular necessity to import foreign tasty cuisine. Furthermore, quality food in Poland is strongly associated with homemade delicacies of 'mom's' or 'grandma's' cooking. Therefore, it is assumed that the use of French accent in a Polish advert may fail to generate a similar association with a good taste as is the case in the UK.

\section{Conclusion}

The comparative study of the two language versions of the advertisement proves problematic assessment of the English version as definitely either linguistically equivalent or localised, as it displays features of both strategies. The analysis of explicitation in the two commercials shows significant linguistic similarities and divergences as well as differences in cultural transfer. On the one hand, the SL advertisement seems more explicit in some parts through the use of semantic superordinates as well as paraphrasing. On the other hand, the TL version proves more explicit in other parts through the use of paraphrasing, synonyms, hyponyms, omission and geographical dialect. The paper, therefore, proves the argument that the amount of lexical equivalence and adaptation (Vinay and Darbelnet, 1958) combined together in the two adverts promotes a case where the translation favours neither linguistic equivalence nor localisation in Sumberg's terms (2004).

The extent of explicitation in the two commercials as illustrated above from the linguistic and cultural perspectives as well as in the parts that display stronger linguistic equivalence also allows to analyse the English translation from the perspective of translation through adaptation (Shuttleworth \& Cowie, 1997). The English commercial has, for instance, an added linguistic layer which was specifically applied with a view to appeal to the British viewer's conceptions of exclusive cuisine and cultural tastes of French food products, the appeal which is absent from the French version. Although it can be questioned how far a translation has to be removed from the content, language and character of the source text to be called adaptation, the two commercials analysed in this paper do display elements where the process is clearly visible. It is, thus, argued that the Perle de Lait advertisement successfully combines adaptation and linguistic equivalence in order to achieve a desired final effect. 


\section{Appendix A}

\section{French advertisement as seen on TV}

1.1. Avant, je ne mangais que des yaourt nature ordinaire, extrement acide.

1.2. J'étais pas terrible.

1.3. Puis un jour, j'ai découvert la douceur de perle de lait et mon visage s'est transformé.

1.4. Perle de lait ce n'est pas un yaourt, c'est beaucoup plus doux.

1.5. Et maintenant succombez au doux parfum vanille de perle de lait saveur vanille.

\section{English backtranslation}

2.1. Before, I only used to eat ordinary natural yoghurt, extremely acidic.

2.2. I wasn't bad.

2.3. Then one day I discovered the softness of Perle de Lait, and my face transformed.

2.4. Perle de Lait is not a yoghurt, it is a lot softer.

2.5. And now succumb to the delicate scent of vanilla of Perle de Lait Vanilla.

\section{English advertisement as seen on TV}

3.1. I used to eat extremely sour yoghurts

3.2. and you could see that I wasn't happy about it.

3.3. Then one day I discovered the silky smoothness of Perle de Lait, and my face lit up.

3.4. Perle de Lait, pleasure makes you beautiful.

3.5. Yield to the temptation of new pleasures.

3.6. Dive into the tiny refreshing taste of Perle de Lait lemon or into the smooth deliciousness of Perle de lait coconut. 


\section{Bibliography}

Austin, J. L. (1990). How To Do Things With Words. Oxford and New York: Oxford University Press.

Bastin, G. L. (2001). Adaptation. In M. Baker (Ed.) Routledge Encyclopedia of Translation Studies (pp. 5-8). London and New York: Routledge.

Blum-Kulka, S. (2004). Shifts of Cohesion and Coherence. In L. Venuti (Ed.) The Translation Studies Reader ( $2^{\text {nd }}$ Edition, pp. 290-305). New York and London: Routledge.

Dryden, J. (1926). Preface to Ovid's Epistles [translated by Several Hands]. In W. P. Ker (Ed.) Essays of John Dryden. New York: Russell and Russell.

Hatim, B. \& Mason, I. (1994). Discourse and the Translator. Harlow: Pearson Education Limited.

Searle, J. R. (1979). Expression and Meaning: Studies in the Theory of Speech Acts. Cambridge: Cambridge University Press.

Shuttleworth, M. \& Cowie, M. (1997). Dictionary of Translation Studies. Manchester: St. Jerome Publishing.

Sumberg, C. (2004). Brand Leadership at Stake: Selling France to British tourists. The Translator 10(2), 329-353.

Torresi, I. (2011). Advertising. In M. Baker \& G. Saldanha (Eds.) Routledge Encyclopedia of Translation Studies (pp. 6-10). London and New York: Routledge.

Valdes, C. (2013). Advertising translation. In C. Millan \& F. Bartrina (Eds.) The Routledge Book of Translation Studies (pp. 303-316). Abingdon and New York: Routledge.

Vinay, J.-P. \& Darbelnet, J. (1958). Stylistyque comparée du français et de l'anglais. Méthode de traduction. Paris: Didier. [J. Sager \& M.-J. Hamel (Transl.) as Comparative Stylistics of French and English: a Methodology for Translation, Amsterdam and Philadelphia: John Benjamins, 1995]. 
